\title{
Understanding Indonesian history, interest in learning history and national insight with nationalism attitude
}

\author{
Johan Setiawan', Aman², Taat Wulandari ${ }^{3}$ \\ ${ }^{1,2}$ Doctoral Program, Graduate Program, Universitas Negeri Yogyakarta, Indonesia \\ ${ }^{3}$ Graduate Program, Universitas Negeri Yogyakarta, Indonesia
}

\section{Article Info \\ Article history: \\ Received Jan 14, 2020 \\ Revised Feb 27, 2020 \\ Accepted Apr 30, 2020}

\section{Keywords:}

Indonesian history

Interest in learning history

National insight

Nationalism attitude

The relationship

\begin{abstract}
The purpose of this study was to investigate the relationship of understanding Indonesian history, interest in learning history and national insight with the nationalism attitude among State Senior High School students in Ngaglik subdistrict, Yogyakarta. The data collection used tests and questionnaires distributed to 126 students who were the respondents, the data were analyzed quantitavely using SPSS version 21. The validity test of the instrument employed biserial point correlation and reliability test using the KuderRichardson Formula 20 (KR 20) formula. Analysis prerequisite tests include normality test, linearity test, and multicollinearity test. The hypotheses were tested using Pearson's product moment correlation and multiple correlation The results of the data analysis shows: (a) there is a positive and significant relationship between understanding Indonesian history with nationalism attitude; (b) there is a positive and significant relationship between interest in learning history and nationalism attitude; (c) there is a positive and significant relationship between national insight and nationalism; and (d) there is a simultaneously positive and significant relationship between understanding of Indonesian history, interest in learning history, and national insight with nationalism attitude.
\end{abstract}

This is an open access article under the CC BY-SA license.

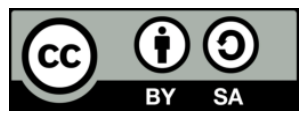

\section{Corresponding Author:}

Johan Setiawan,

Doctoral Program, Graduate Program,

Universitas Negeri Yogyakarta,

Jalan Palagan Tentara Pelajar, Sleman, Yogyakarta, Indonesia.

Email: johansetiawan.2019@student.uny.ac.id

\section{INTRODUCTION}

The Indonesian nation is a pluralistic nation that is a nation consisting of various ethnic groups, races, religions, and cultural systems. The identity of the Indonesian people cannot be separated from the existence of diversity in Indonesian nation. As a pluralistic nation, an accommodative attitude is needed to embrace all groups. One group with another group must respect each other and live side by side (coexistence) peacefully. However, the challenge that is happening today is the rapid flow of globalization which actually has a negative impact on Indonesia's plurality.

The rapidity of technology and information raises a phenomenon of nationalism which tends to lead to the degradation of the spirit of nationalism and understanding of Indonesian nationalism. The waning of national insight is caused by: (1) The desire of some regions to separate themselves from the unitary state of the Republic of Indonesia or it is known as Negara Kesatuan Republik Indonesia (NKRI), this reflects the occurrence of disintegration; (2) The strengthening of the spirit of primordialism and the growth of 
separatist symptoms; and (3) The use of violence and majority coercion creates conflicts between ethnicities, as well as religions in some areas $[1,2]$.

The conflict indicates that the sense of unity and integrity of the Indonesian people began to be questioned. Globalization which is accompanied by a revolution in the field of ICT (Information and Communication Technology) has an effect on the fading of the value of nationalism among students. Students as young generation in Indonesia who are the backbone of the nation have been poisoned by various impacts caused by globalization [3].

Based on observations in several schools that are used as research sites, the waning attitudes of nationalism among students because of the impact of globalization are characterized by a lack of respect for diversity and differences, reduced sense of solidarity, did not memorizing Indonesian songs, not memorizing Pancasila, not loving domestic products, not knowing the names of the national hero, not following the flag ceremony properly, not understanding the milestones of the nation's historical struggle, and not remembering the services of heroes by not attending the memorial service of the heroes' day.

Education is the main key to the life of the Indonesian nation as an effort to educate the nation's children, change the attitude of students to have good character [4-8]. One form of education to answer this challenge is the implementation of Indonesian history subject at the high school level. History is a subject that instills knowledge [9, 10], attitudes, values regarding the process of change and development of Indonesian society from the past to the present [11]. Learning history in schools needs to be carried out to build a scientific perspective with a time perspective, shared memory, and awareness of the core values of the nation to shape identity [12]. Learning history as an element of the development of cultural nationalism is very functioning to be a mediation in establishing relations between the elements of society in Indonesia that are pluralistic in nature [13].

Nationalism insight can be applied through history learning in schools [14]. Indonesian history lessons that implement national insights in historical learning material are very important to instill the attitude of nation and state, in which contain many values of accepting and appreciating diversity, tolerance, national unity, national love, and raising awareness of the crisis of solidarity to pluralism which leads to division so that it can be overcome, these values are part of nationalism. Therefore, understanding Indonesian history which implements national insights can know deeply and be able to capture not only knowing, remembering the numbers of years and various historical events that are understood as a collective record of the past of Indonesian nation. A historical event is only directly meaningful in people's lives if the historical event can be understood objectively, listening to the causes of historical events and trying to draw lessons on what happened in the past.

In order to make the students to grasp the meaning in history learning, teachers are required to foster students' interest in learning so they can be interested in history lessons. The teachers in their efforts to foster students' interest in learning need to work together and create the history learning in the class which is more attractive to students. For example, in history learning, teachers need to use interesting and creative learning models and media such as using variations in methods, the internet, film, and images. Therefore, the students are interested in following the learning process of Indonesian history, which is full of values of unity and nationalism that will be easily obtained by students. The success of students in taking education is influenced by various factors, one of which is the interest in learning. High interest in learning will help students to get a good learning process.

The characteristics of historical subjects in high school according to Aman [15], is that history lessons have a strategic meaning in the formation of dignified character, attitudes and civilization as well as in the formation of Indonesian people who have a sense of nationality, tolerance and nationalism. Attitude is a mental position with regard to fact or state or a feeling or emotion toward a fact or state [16]. Attitudes as relatively lasting clusters of feelings, beliefs, and behavior tendencies directed towards specific persons, ideas, objects or groups [17]. Attitudes are closely related to a person's condition in acting on an existing fact. This action gives a certain behavior that arises in a person, including his nationalism attitude [18].

Nationalism refers to a situation where one owns his/her allegiance absolutely to a particular nation or ethnic group that forms a political nation [19]. Citizen loyalty to the state is a natural extension of national tolerance and solidarity (culture, language, and ethnicity). States nationalism is a way of seeing human society primarily consisting of discrete, different nations, each with an obvious right to exist and to command loyalty [20]. Nationalism is a kind of national emotion based ideology; this is the love and loyalty of citizens for the nation itself, including inheritance and maintenance by citizens such as customs, language, and religion [21, 22]. The attitude of nationalism in the context of Indonesian Nationalism consists of an awareness of unity to respect and appreciate each other because Indonesia is inhabited by various tribes, cultures and religions. Nationalism could be understood by creating and maintaining the sovereignty of 
a state (nation), to realize the concept of a common identity of a group of Indonesian nationalism for humanity's group [23].

With the existence of this understanding of nationalism, it wants to achieve and maintain the unity that has been fostered to last a nation. Because in Indonesia's history, unity has been established with the existence of tolerance as evidenced by the oath of youth and experiencing the peak of nationalism with the proclaiming of Indonesian independence. The spirit of the event must be maintained and transformed to the students through learning Indonesian history in high school.

Various studies have been carried out on nationalism attitudes. Previous research has focused on the ability to clarify historical values [24], perspective on cultural diversity [25], and focus on character [26]. This research focuses on efforts to investigate the relationship of understanding Indonesian history, interest in learning history, and national insight with the nationalism attitude of students. The author believes the understanding of Indonesian history, interest in learning and good national insight will influence the nationalism attitude of the students of State Senior High Schools in Ngaglik District, Yogyakarta.

Understanding Indonesian history is a process of building understanding of subject matter [27, 28]. This understanding can be obtained from the students' knowledge so that they are able to capture the meaning in the subject matter of Indonesian history, therefore, by this experience in learning is expected to be able to find the meaning of a historical material. Indonesian history is a reconstruction or depiction of how the lives of the Indonesian people have experienced their development through historical processes so that they appear as they are today [29]. It is this process of development which gradually and continually embodies the integration of current national unity. Indonesian history depicts various events that cover a very long span of time, the period of Indonesian history starting from the Pre-Literary Period to the Reformation Period.

The Indonesian history lesson which is taught in high school aims to teach tolerance and strengthen the sense of nationalism [30]. By examining various historical events in Indonesia to build a collective memory in students, so that they know the history of their nation and they are able to recognize their national identity. The understanding Indonesian history is knowing deeply and being able to capture the meaning of a series of historical events that took place in Indonesia. It is expected that the understanding which has been possessed by students can internalize the values contained in Indonesia's historical events, in order to have a good attitude of nationalism.

Second, interest in learning history is a fixed tendency and an urge to pay attention in learning activities [31]. Learning activities as a way of changing students towards positive things, because when studying a subject, it is expected to be able to think and behave [32]. Learning can make students face their inability to change into thinking more and innovative [33]. The interest in learning is driven by love and interest, it can affect the level and continuity of involvement in learning and the depth of understanding reached by students [34] in this case the history subjects.

Interested in something means that care about it and that me have (mostly) positive feelings towards it [35]. Feeling happy and interested in studying history make someone has a high attention to history lessons; it can help someone easy to learn history. Students who are interested will study the material contained in history lessons seriously because there is an attraction for them. The interest in learning history will determine the emergence of feelings of pleasure and attention for students in learning history.

State that learning is an activity that begins with creating a feeling for the learning process to occur [36]. The interest in learning can produce an attitude which is a readiness to do if there is a special stimulus in accordance with existing circumstances and can make students develop [37]. Thus, there needs to be an effort to increase students' interest in learning history, by means of varied learning strategies, so students will be interested and be active in the learning process [38, 39].

Third, national insight is the result of the development of the dynamics of nationalism in achieving the nation's ideals, the rationalization of sense and nationalism insight which create nationalism [26]. The realization of the existence of unity consists of cultural and ethnic diversity will create the nationalism attitude of students. The implementation of national insights in learning Indonesian history is done by compiling syllabus and lesson plans that internalize national character values [14] including accepting and appreciating diversity, cooperation, love, unity, tolerance, responsible freedom, self discipline, and solidarity.

Regarding to the nationalism, the teacher views that national insights in learning history can be carried out through Indonesian historical material related to national insight. The example is in the history of Kebangkitan National Indonesia (National Awakening of Indonesia) material [40] is marked by the Sumpah Pemuda (Youth Vows). It shows unity because Indonesia is a unitary state consisting of diverse ethnicities, cultures and religions as shown by the motto Bhinneka Tunggal Ika (Unity in Diversity) [41].

Int. J. Eval. \& Res. Educ. Vol. 9, No. 2, June 2020: 364 - 373 


\section{RESEARCH METHOD}

This study was a quantitative research approach employed correlational design. The quantitative approach is used because it is done in a particular population or sample [42] and find out the relationship between understanding Indonesian history, interest in learning history, and national insight with nationalism attitude of senior high school students in Ngaglik subdistrict, Sleman, Yogyakarta as shown in Table 1. Correlational method is used because it aims to find the relationships between the variables studied. This research was carried out in all Public High Schools in Ngaglik subdistrict, namely State Senior High School 1 and State Senior High School 2 of Ngaglik, Sleman, Yogyakarta. The population in this study was 187 students, sample obtained were 126 students using calculation formulas Riduwan and Akdon. Data were analyzed quantitatively using product moment correlation analysis techniques and multiple correlations [43].

Table 1. Research characteristics

\begin{tabular}{lcccccc}
\hline \multirow{2}{*}{ School } & \multirow{2}{*}{ Class } & \multirow{2}{*}{ Population } & \multirow{2}{*}{ Determination Sample } & Sample & \multicolumn{2}{c}{ Gender } \\
& & & & M \\
\hline \multirow{2}{*}{ SMAN 1 } & XI IPS 1 & 30 & $30 / 187 \times 126=20.21$ & 20 & 13 & 7 \\
& XI IPS 2 & 31 & $31 / 187 \times 126=20.88$ & 21 & 11 & 10 \\
& XI IPS 3 & 32 & $32 / 187 \times 126=21.56$ & 22 & 15 & 7 \\
\multirow{2}{*}{ SMAN 2 } & XI IPS 1 & 30 & $30 / 187 \times 126=20.21$ & 20 & 13 & 7 \\
& XI IPS 2 & 28 & $28 / 187 \times 126=18.86$ & 19 & 11 & 8 \\
Total & XI IPS 3 & 36 & $36 / 187 \times 126=24.25$ & 24 & 14 & 10 \\
\hline
\end{tabular}

\subsection{Measurement}

The instrument used in this study was a test of understanding Indonesian history, questionnaire on interest in learning history, questionnaire on national insight and questionnaire on nationalism attitude. Tests of understanding Indonesian history in multiple choice forms with five alternative answers, namely a, b, c, d, and e with regard to aspects of memory, understanding, application, analysis, synthesis and evaluation. Each respondent was instructed to choose the correct answer among the alternative answers given. For the correct answer a score of 1 (one) is given, while the wrong answer is given a score of 0 (zero). Questionnaire on interest in learning history, national insight and nationalism attitude using dichotomy interval scale only with 'yes' and 'no', because researchers want to get a firm answer to a problem being asked. Therefore, the alternatives are positive and negative answers.

\subsection{Validity and reliability}

The validity of the instrument uses content and constructs validity [44]. Content validity is by consulting the indicators to be measured and achieving the objectives to be achieved in expert judgment. Construct validity uses biserial point correlation formula. The result of the variable validity of test of understanding Indonesian national history showed as many as 18 questions declared valid because the correlation value $>0.254[45,46]$ while 7 items were invalid. The results of the variable validity of interest in learning history, national insight, and nationalism attitudes questionnaires showed that 22 statements were valid because the correlation value was $>0.254$, while the 3 questionnaires were invalid. Reliability testing in this study used the KR 20 coefficient formula. Instruments are said to be reliable if they have a reliability coefficient of 0.6 [45]. The results of reliability testing for instruments of understanding Indonesian national history $\left(\mathrm{X}_{1}\right)$, historical learning interest $\left(\mathrm{X}_{2}\right)$, national insight $\left(\mathrm{X}_{3}\right)$ and nationalism $(\mathrm{Y})$ have values greater than 0.6 , so it can be concluded that all instruments used are reliable. Then, the collected data is processed and analyzed with descriptive techniques, analysis prerequisite test and hypothesis testing.

\subsection{Analysis prerequisite tests}

Analysis prerequisite tests include normality test, linearity test, and multicollinearity test. The normality test of the data is done by using the Kolmogorov-Smirnov Test with data collection guidelines if the Kolmogorov-Smirnov- $Z$ value is greater than the critical value or the $p$ value $>0.05$, then the data distribution is normal $[6,45]$. Data linearity test uses coefficient $F$ test with data retrieval guidelines if the $F_{\text {value }}<F_{\text {table }}$ then data is linear [45]. Multicollinearity testing is carried out if the tolerance value is less than 0.1 or the VIF value is more than 10, so the predictor is multicollinear [45]. Hypothesis testing uses product moment correlation and multiple correlations. The testing criteria in this study are as follows: Ho is rejected if $r_{\text {value }}>r_{\text {table }}$ and $p>0.05$. 


\section{RESULTS AND DISCUSSION}

\subsection{Descriptive analysis}

The value of understanding Indonesian history is obtained from the distribution of test questions with 18 items with a value of $0-1$, so that the ideal highest value is 18 . Based on the score range, the ideal mean is $18 \div 2=9$ and the ideal standard deviation is $18 \div 6=3$. Most respondents have a value of understanding Indonesian national history in a good category, there are 52 respondents $(41.3 \%)$. The score of interest in learning history is obtained from the distribution of questionnaires with as many as 22 items with a value of $0-1$, the statement items are divided into two criteria consisting of positive statements and negative statements. The ideal highest value is 22 . Based on the range of scores, the ideal mean is $22 \div 2=11$ and the ideal standard deviation is $22 \div 6=3.67$. Most respondents have the value of interest in learning in the good category; there are 35 respondents $(27.8 \%)$. National insight scores are obtained from the distribution of questionnaires with as many as 22 items with a value of $0-1$, the statement items are divided into two criteria consisting of positive statements and negative statements. The ideal highest value is 22 . Based on the range of scores, the ideal mean is $22 \div 2=11$ and the ideal standard deviation is $22 \div 6=3.67$. Most of the respondents have national insight values in a very good category, which is 95 respondents $(75.4 \%)$. Nationalism attitude scores are obtained from the distribution of questionnaires with as many as 22 items with a value of $0-1$, statement items are divided into two criteria consisting of positive statements and negative statements. The ideal highest value is 22 . Based on the range of scores, the ideal mean is $22 \div 2=11$ and the ideal standard deviation is $22 \div 6=3.67$. Most of the respondents have national insight values in a very good category, which is 62 respondents $(49.2 \%)$.

\subsection{Prerequisite analysis test}

Normality test is to determine whether the data distribution is normal or not uses Kolmogorov Smirnov by comparing the probability value with a significance value of 0.05 . Based on the calculation results the $p$ value on the variable of understanding Indonesian national history is 0.103 or greater than 0.05 , the data for that variable has an equal distribution (normal). The $\mathrm{p}$ value on the learning interest variable is 0.107 or greater than 0.05 ; the data for this variable has an equal distribution (normal). The $\mathrm{p}$ value of the national insight variable is 0.122 or greater than 0.05 ; the data for this variable has an equal distribution (normal). The $\mathrm{p}$ value on the nationalism attitude variable is 0.178 or greater than 0.05 ; the data for this variable has an equal distribution (normal).

The guideline used is if the value of $F_{\text {count }}<F_{\text {table }}$ then the data is linear. The $F_{\text {count }}$ between the understanding of Indonesian national history $\left(\mathrm{X}_{1}\right)$ and the nationalism attitude $(\mathrm{Y})$ is 1.584 or smaller than $\mathrm{F}_{\text {Tabel }} 1.83$ with a significant 0.100 or greater than 0.05 , the relationship between the two variables is linear. The $\mathrm{F}_{\text {count }}$ value between historical learning interests $\left(\mathrm{X}_{2}\right)$ with nationalism $(\mathrm{Y})$ attitude is 1.345 or smaller than $\mathrm{F}_{\text {Table }} 1.72$ with a significant 0.171 or greater than 0.05 , the relationship between the two variables is linear. The $\mathrm{F}_{\text {count }}$ value between national insights $\left(\mathrm{X}_{3}\right)$ with nationalism $(\mathrm{Y})$ attitudes is 0.881 or smaller than $\mathrm{F}_{\text {Table }} 1.90$ with a significant 0.546 or greater than 0.05 , the relationship between the two variables is linear.

Multicollinearity testing is carried out if the tolerance value is less than 0.1 or the VIF value is more than 10 , so the predictor is multicollinear. Based on the results of calculations, the tolerance values on the variable of understanding Indonesian national history of 0.890 and VIF values of 1.123 , there are no symptoms of multicollinearity. Tolerance value on the interest of learning history variable is 0.824 and VIF value is 1.213 so there are no symptoms of multicollinearity. Tolerance value in the national insight variable is 1.797 and VIF value is tolerance 1.254 so there are no symptoms of multicollinearity

\subsection{Hypothesis testing}

The use of this analysis is to examine whether there is a relationship between understanding Indonesian national history, interest in learning history and nationalism attitude. Data analysis is done by product moment correlation analysis, which consists of Pearson product moment and multiple correlations. The guideline for decision making in this study is (a) If the $r_{\text {count }}$ is greater than $r_{\text {table }}$, the hypothesis is accepted; (b) If $r_{\text {count }}$ is smaller than $r_{\text {table }}$, the hypothesis is rejected. The sample in this study was 126 students with a significance level of $5 \%$, and then the $r_{\text {table }}$ of 0.176 is obtained. Table 2 shows the summary results of Pearson product moment test. 
Table 2. Summary results of pearson product moment test

\begin{tabular}{cccccc}
\hline \multicolumn{6}{c}{ Correlations } \\
& & $\left(\mathrm{X}_{1}\right)$ & $\left(\mathrm{X}_{2}\right)$ & $\left(\mathrm{X}_{3}\right)$ & $(\mathrm{Y})$ \\
\hline & $\mathrm{P}$ & 1 & 0.245 & 0.301 & 0.447 \\
$\left(\mathrm{X}_{1}\right)$ & Sig. & & 0.006 & 0.001 & 0.000 \\
& $\mathrm{~N}$ & 126 & 126 & 126 & 126 \\
& $\mathrm{P}$ & 0.245 & 1 & 0.398 & 0.432 \\
$\left(\mathrm{X}_{2}\right)$ & $\mathrm{Sig}$. & 0.006 & & 0.000 & 0.000 \\
& $\mathrm{~N}$ & 126 & 126 & 126 & 126 \\
& $\mathrm{P}$ & 0.301 & 0.398 & 1 & 0.681 \\
$\left(\mathrm{X}_{3}\right)$ & Sig. & 0.001 & 0.000 & & 0.000 \\
& $\mathrm{~N}$ & 126 & 126 & 126 & 126 \\
& $\mathrm{P}$ & 0.447 & 0.432 & 0.681 & 1 \\
$(\mathrm{Y})$ & Sig. & 0.000 & 0.000 & 0.000 & \\
& $\mathrm{~N}$ & 126 & 126 & 126 & 126 \\
\hline & & & & &
\end{tabular}

\subsubsection{Testing the first hypothesis $\left(\mathrm{X}_{1}-\mathrm{Y}\right)$}

Based on the results of the Pearson product moment test between understanding Indonesian history with nationalism attitudes, the value of $r_{\text {count }}=0.447$. Then the $r_{\text {count }}$ is consulted with $r_{\text {table }}=0.176$, then

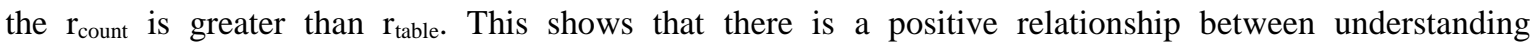
Indonesian national history with nationalism attitude. The significance value between the variables of understanding Indonesian national history with the nationalism attitude is equal to 0.000 . A significance value of 0.000 is smaller than 0.05 so it can be written $0.000<0.05$. This shows that there is a significant relationship between understanding Indonesian history with nationalism attitude. From the analysis that has been done, it is explained that this first hypothesis is acceptable. There is a positive and significant relationship between the understanding of Indonesian history and the nationalism attitude.

\subsubsection{Testing the second hypothesis $\left(\mathrm{X}_{2}-\mathrm{Y}\right)$}

Based on the results of the Pearson product moment test between interest in learning history and nationalism attitude, the value of $r_{\text {count }}=0.432$. Then the $r_{\text {count }}$ is consulted with $r_{\text {table }}=0.176$, then the $r_{\text {count }}$ is

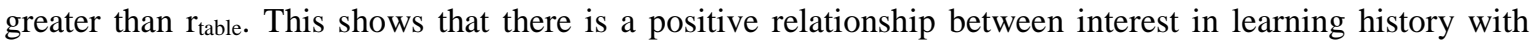
nationalism attitude. The significance value of the interest in learning history with nationalism is 0.000 . A significance value of 0.000 is smaller than 0.05 so it can be written $0.000<0,05$. This shows that there is a significant relationship between interests in learning history with nationalism attotude. From the analysis that has been done, it is explained that this second hypothesis is acceptable. There is a positive and significant relationship between interest in learning history and nationalism attitude.

\subsubsection{Testing the third hypothesis $\left(\mathrm{X}_{3}-\mathrm{Y}\right)$}

Based on the results of the Pearson product moment testing between national insight and nationalism attitude, the value of $r_{\text {count }}=0.681$. Then the $r_{\text {count }}$ is consulted with $r_{\text {table }}=0.176$, then the $r_{\text {count }}$ is greater than $r_{\text {table }}$. This shows that there is a positive relationship between national insight and nationalism attitude. The significance value of the national insight variable with nationalism is 0.000 . A significance value of 0,000 is smaller than 0.05 so it can be written $0.000<0.05$. This shows that there is a significant relationship between national insight and nationalism. From the analysis that has been done, it is explained that this third hypothesis is acceptable. There is a positive and significant relationship between national insight and nationalism attitude.

\subsubsection{Testing the fourth hypothesis $\left(\mathrm{X}_{1}, \mathrm{X}_{2}, \mathrm{X}_{3}-\mathrm{Y}\right)$}

Based on the results of testing multiple correlations between historical understanding, interest in learning history and national insights with nationalism attitudes, the value of $r_{\text {count }}=0.740$. Then

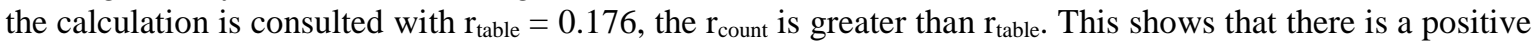
relationship between understanding Indonesian history, interest in learning history and national insight with nationalism attitude. Testing the significance of the relationship of understanding Indonesian history, interest in learning history and national insight with nationalism attitudes was carried out using the $\mathrm{F}$ test, so that $\mathrm{F}_{\text {count }}$ obtained was 49.269. The price is compared to $\mathrm{F}_{\text {table }}$ with $\mathrm{dk}$ numerator $=2$ and the denominator $=126-2-1=123$, for error $5 \%$ the price of $F_{\text {table }}$ is 3.07 . Thus, $F_{\text {count }}$ is greater than $F_{\text {table }}$ $\left(\mathrm{F}_{\text {count }} 49.269>\mathrm{F}_{\text {table }} 3.07\right)$.

This shows that there is a significant relationship between understanding Indonesian history, interest in learning history and national insight with nationalism attitude. From the analysis that has been done, it is explained that this fourth hypothesis is acceptable. There is a positive and significant relationship between understanding Indonesian history, interest in learning history, nationalis insight with nationalism attitude. 
Based on the results of the calculation, it can be seen the contribution of variable understanding of Indonesian national history, interest in learning history and national insight with nationalism attitude from the coefficient of determination of $54.8 \%$, while the remaining 45.2 is influenced by other variables outside of research. The results of multiple correlation calculations are:

Table 3 Double correlation test results

\begin{tabular}{ccccccc}
\hline Correlation & $\mathrm{N}$ & Double Correlation Coefficients & R. Square & $F$ & $P$ Sig & Notes \\
\hline $\mathrm{X}_{1} \mathrm{X}_{2} \mathrm{X}_{3}-\mathrm{Y}$ & 126 & 0.740 & 54.8 & 49.269 & 0.000 & Positive and Significant \\
\hline
\end{tabular}

\subsection{Discussion}

\subsubsection{Relationship between understanding Indonesian national history and the nationalism attitude}

The understanding of Indonesian history has a positive and significant relationship with the nationalism attitude, so that if the understanding of Indonesian history is high, the nationalism of students will be higher. This research is almost the same as the research conducted by Susanto [25], the study shows that there is a positive correlation between understanding Indonesian history with students' nationalism. If students understand the national history of Indonesia, the better the nationalism is. The nationalism attitude of students in the study is a positive thing gained from understanding Indonesian national history.

According to Kochhar, there is a relationship between Indonesian history and the nationalism attitude [30]. The research relationship that is intended, understanding is the process that makes knowledge belongs to someone and will ultimately affect the process of thinking and acting individually. The ability to understand is very important to achieve procedural knowledge, which is to understand the meaning or concept, situation and facts that someone knows. Therefore, from this understanding will shape the mindset and behavior of students. Instilling an understanding of the Indonesian past is one of the goals in learning Indonesian history at school.

Students need to be given an understanding of the history of the Indonesian nation to foster an attitude of nationalism through appreciation of the values of our nation's past. By examining various historical events in Indonesia to build a collective memory in students, so that they know the history of their nation, are able to recognize their national identity and make it a foundation in building the life of the nation and state for today and in the future. Education is a process of internalizing values including the value of nationalism. Understanding is one of the important aspects of the process of internalizing the value of nationalism. Historical understanding in this regard of the Indonesian history is a process of planting nationalism through awareness of the historical reality that shapes national identity.

\subsubsection{Relationship between interest in learning history with the attitude of nationalism}

The interest in learning history has a positive and significant relationship with the nationalism attitude, so that if the interest in learning history is high then the nationalism attitude of students will also be higher. This research is almost the same as the results of previous study conducted by Hizam [24] which explains that the interest in learning history of students will provide a more in-depth possibility of historical meaning contained in a set of historical facts and will contribute to the formation of student nationalism.

Nationalism is a form of highest loyalty to the maintenance of the nation's life and the development of the nation's potential and prevention of all forms that endanger the existence of the nation. Tohirin there is a relationship between interests in learning history with nationalism attitude [31]. The relationship is intended that interest in learning is explained as a tendency to give attention along with feelings of pleasure that tends to remain in learning history. This is by having an interest in studying Indonesian national history, which is full of nationalist values that will be easily absorbed by students. The aim of Indonesian history lessons is the aspect of nationalism, students who have a high interest will be easy to understand history lessons and form nationalism attitudes well.

\subsubsection{Relationship between national insight and nationalism}

National insight has a positive and significant relationship with the nationalism attitude, so that if national insight is high, the nationalism attitude of students will also be higher. This research is almost the same as the results of previous studies conducted by Kusmayadi [26] which explain that between national insight and nationalism attitude has a relationship. The level of nationalism attitude in a person will influence the national insight. Indonesian people who have a high nationalism attitude will certainly be followed by good national insight. Nationalism that has the meaning of national unity and integrity, if it is good then the attitude of nationalism will be good. 
National insight creates a nationalism that is a national mind or view, in which a nation has life goals and national goals [47]. The embodiment of the unity and integrity of the nation which consists of ethnic and cultural diversity will create the nationalism attitude of students. The basic values of national insight from the nation's unity and integrity are used as a force to fix the Indonesian people in fostering their identity to form their nationalism.

This is evidenced by the high contribution between national insight and nationalism. Those who have a high understanding of the history of the Indonesian movement tend to have an attitude of mutual respect and appreciation that has been built in the process of understanding. Therefore, it will automatically make a real contribution to the national insight which leads to the formation of nationalism attitude. This means that national insight has a positive and significant relationship with nationalist attitudes, so that if national insight is high, nationalism attitude of students will also be higher.

\subsubsection{Relationship between understanding Indonesian history, interest in learning history and national insight with the attitude of nationalism}

The understanding of Indonesian history as well as interest in learning history and national insight has a significant relationship with nationalism. The results of the study explain that understanding Indonesian history has a relationship with the nationalism attitude. That historical material contains the values of heroism, exemplary, pioneering, patriotism, nationalism, and unyielding spirit which underlie the process of forming the character and personality of students; contains the repertoire of civilizations of nations, including the Indonesian civilization [15]. In history learning contains material on Indonesian civilization in which there are values that are able to shape the character and personality of students, one of which is nationalism. Students who have a high understanding of Indonesian history will also have a high attitude of nationalism. The interest in learning as a feeling of being like more and feeling attached to something or activity without being told, one of which is a history lesson that contains a lot of national character education [48]. When students have a high interest in learning, they will understand the material contained in the learning. It can be concluded that students who have a high interest in learning history have a high attitude of nationalism.

Research on national insight is essential for character building, especially nationalism. Indonesian history education about the material of struggle of the nation and the movement of the nation has a close relationship in the process of forming a nationalism attitude. From these various diversities, the mutual tolerance of the Indonesian people which consists of diverse tribes, religions, and different cultures appears. National unity can be realized with the existence of nationalism insight, and leads to an attitude of nationalism. From the results of the research above, it can be concluded that understanding Indonesian history, interest in learning history and national insight with nationalism has a positive and significant relationship. If the understanding of Indonesian history, interest in learning history, and national insight are high, the nationalism attitude of students will be even higher and vice versa.

\section{CONCLUSION}

There is a positive and significant relationship between understanding Indonesian history, interest in learning history, national insight with attitude of nationalism. The results of this study can be used as a reference or source of theory that can be used as supporting material in research related to the material. Based on this research, it can be used as a consideration for the school and parents to always work together in controlling and responding to student behavior wisely so that students can have good character values.

\section{REFERENCES}

[1] J. Adam, Communal violence, forced migration and social change on the island of Ambon, Indonesia, Belgia: Ghent University, 2010.

[2] F. S. Sofyan, "The relationship of the national identity course with increased nationality insights and the spirit of student nationalism (Correlation studies within the PPKN study program at Buana Perjuangan University, Karawang (in bahasa)," Jurnal CIVICS, vol. 2, no. 1, pp. 68-81, 2017.

[3] S.T. Sulistiyono, "The importance of Indonesia's Nationalism revitalization in the globalization era: a historical perspective," Journal of Maritime Studies and National Integration, vol. 2, no. 1, pp. 1-15, 2018.

[4] A. Ari, "Finding acceptance of bloom's revised cognitive taxonomy on the international stage and in Turkey," Educational Sciences: Theory \& Practice, vol. 11, no. 2, pp. 767-772, 2011.

[5] A. Azis, H. Joebagio, and Sudiyanto, "Correlation between: Understanding of nationalism and historical consciousness toward students' democratic attitude in Banda Aceh senior high school," International Journal of Multicultural and Multireligious Understanding, vol. 5, no. 3, pp. 60-71, 2018.

[6] Fahruddin and Sugiyono, "Teacher performance, nationalistic attitude, and historical awareness, relationship with learning achievement," Journal of Education and Practice, vol. 9, no. 21, pp. 28-35, 2018. 
[7] S.H.P Lin and Y.K. Jia, "Relationships between LINUS teachers' knowledge of basic language constructs, teaching experience and perceived teaching abilities," Universal Journal of Educational Research, vol. 6, no. 9, pp. 1962-1973, 2018

[8] L.S. Ling and Y.K. Jian, "Students' perceived learning environment for self regulation," Indian Journal of Public Health Research \& Development, vol. 10, no. 4, pp. 1454-1459, 2019.

[9] Aman, "History Teachers' competence in implementing authentic assessment: A case study in a state senior high school in Yogyakarta," International Journal of Learning, Teaching and Educational Research, vol. 18, no. 10, pp. 68-88, 2019.

[10] Sever and Ersoy, "Becoming a teacher educator: Journey of a primary school teacher," Eurasian Journal of Educational Research, vol. 83, pp. 81-102, 2019.

[11] G. Guven and N. K. Cakir, "The relation between teachers' attitudes towards renewable energy sources and critical thinking dispositions," Journal of Baltic Science Education, vol. 18, no. 5, pp. 717-731, 2019.

[12] R. Andrews, C. McGlynn, and A. Mycock, "National pride and students' attitudes towards history: An exploratory study," Educational Studies, vol. 36, no. 3, pp. 299-309, 2010.

[13] Sariyatun, H. Joebagio, and B. Sumardjoko, "Proliferation of democratic education in Indonesia: The influence measurement of tolerance, multiculturalism, and historical awareness on the democratic attitude," Jurnal New Educational Review, pp. 113-123, 2018.

[14] M. Anis, "Nationality insight implementation at islamic boarding school in history learning at Al-Muayyad Surakarta high school and Muhammadiyah high school of boarding school Yogyakarta," Jurnal Sriwijaya Historia, vol. 1, no. 1, pp. 1-10, 2017.

[15] Aman, Historical learning evaluation model (in bahasa), Yogyakarta: Ombak, 2011.

[16] H. Chaiklin, "Attitudes, behavior, and social practice," The Journal of Sociology \& Social Welfare, vol. 38, no. 1, pp. 31-54, 2011

[17] V. Jain, "3D model of attitude," International Journal of Advanced Research in Management and Social Sciences, vol. 3, no. 3, pp. 1-12, 2014.

[18] C. Toraman, H. F. Ozdemir, K. A. M. Aytug and S. Orakc1, "Relationships between cognitive flexibility, perceived quality of faculty life, learning approaches, and academic achievement," International Journal of Instruction, vol. 13, no. 1, pp. 1-17, 2019.

[19] T. C. Adetiba and A. Rahim, "Between ethnicity, nationality and development in Nigeria", International Journal of Development and Sustainability, vol. 1, no. 3, pp. 656-674, 2012.

[20] J. Leerssen, National thought in europe: A cultural history. Amsterdam: Amsterdam University Press, 2006.

[21] Y. Zhang, "Analyzing the connotation of Mao Zedong's nationalism," International Journal of Social Science Studies, vol. 2, no. 1, pp. 65-69, 2014.

[22] E. Ismawati, "Nationalism in Indonesian literature as active learning material," International Journal of Active Learning, vol. 3, no. 1, pp. 33-48, 2018.

[23] H. Susanto, "Understanding of regional history and perception of cultural diversity in developing nationalism," Jurnal Historia: International Journal of History Education, vol. 14, no. 1, pp. 91-100, 2013.

[24] I. Hizam, "Contribution of Interest in Study and Ability to Clarify Historical Values on Forming an Attitude of Nationalism (in bahasa)," Jurnal Penelitian Keislaman, vol. 3, no. 2, pp. 287-300, 2007.

[25] H. Susanto, "Understanding of Indonesian history and perspectives on cultural diversity in fostering an attitude of nationalism (correlation study on student education history of IKIP Unlam)," Jurnal sejarah dan budaya, vol. 9, no. 1, pp. 39-50, 2015.

[26] Y. Kusmayadi, "The relationship between understanding of Indonesian national history and nationality insights with student character (study of the history of FKIP students at Galuh Ciamis University)," Jurnal Agastya, vol. 7, no. 2, pp. 1-19, 2017.

[27] Aman, "The development of "be a scientist" media images in learning social sciences subject for junior high school," Journal of Critical Reviews, vol. 7, no 2, pp. 793-796, 2020.

[28] A. P. Gilakjani and N. B. Sabouri, "How can students improve their reading comprehension skill?" Journal of Studies in Education, vol. 6, no. 2, pp. 229-240, 2016.

[29] S. Kartodirdjo, Introduction to new Indonesian history: 1500-1900 from emporium to imperium (in bahasa), Yogyakarta: Ombak, 2016.

[30] S. K. Kochhar, Historical learning (in bahasa), Jakarta: Grasindo, 2008.

[31] Tohirin, Psychology of islamic education learning (in bahasa), Jakarta: Rineka cipta, 2008.

[32] A. Kara, "The effect of a learning theories' unit on students' attitudes toward learning," Australian Journal of Teacher Education, vol. 34, no. 1, pp. 100-113, 2009.

[33] A. A. A. Awwad, "Piaget's theory of learning," Interdisciplinary Journal of Contemporary Research in Business, vol. 4, no. 9, pp. 106-129, 2013.

[34] B. Mcgaw and R. Watanabe, Learning for tomorrow's world: Firs results from Pisa 2003, Paris: OECD, 2004.

[35] J. M. Harackiewicz and C. S. Hulleman, "The importance of interest: The role of achievement goals and task values in promoting the development of interest, social and personality psychology compass," Journal Compilation Blackwell Publishing Ltd, vol. 4, no. 1, pp. 42-52, 2010.

[36] R.C. Richey, D.C. Fields, and M. Foxon, Instructional design competencies: The standards. third edition, New York: Clearinghouse on Instructional and Technology, 2001.

[37] H. Dumont, D. Istance, and F. Benavides, The nature of learning using research to inspired practice, OECD Press, 2010.

Int. J. Eval. \& Res. Educ. Vol. 9, No. 2, June 2020: 364 - 373 
[38] P.R. Subramaniam, "Motivational effects of interest on student engagement and learning in physical education: a review," International Journal of Physical Education, vol. 46, no. 2, pp. 11-20, 2009.

[39] C. Park, "Engaging students in the learning process: The learning journal," Journal of Geography in Higher Education, vol. 27, no. 2, pp. 183-199, 2013.

[40] Nuryanti, "Implantation of Nationalist Insights in Islamic Boarding Schools through History Learning (in Bahasa)," Jurnal Pawiyatan, vol. 21, no. 1, pp. 124-34, 2014.

[41] Subaryana, "The impact of history learning to nationalism and patriotism attitudes in the globalisation era," Jurnal Historia: International Journal of History Education, vol. 8, no. 1, pp. 41-56, 2012.

[42] B.R. Werang, M. Betaubun, and E. A. G. Pure, "Factors influencing teachers' organizational commitment (case study on primary schools' teachers in remote area of merauke regency, Papua, Indonesian," Journal of Educational Policy and Entrepreneurial Research (JEPER), vol. 2, no. 10, pp. 122-130, 2015.

[43] B.R. Werang, "The effect of workload, individual characteristics, and school climate on teachers' emotional exhaustion in elementary schools of Papua," Cakrawala Pendidikan, vol. 37. no. 3, pp. 457-469, 2018.

[44] U. Ulucinar and Ari, "The development of caring thinking skills inventory based on problem scenarios: a study of validation and reliability," Universal Journal of Educational Research, vol. 7, no. 6, pp. 1414-1429, 2019.

[45] Sugiyono, Statistics for Research (in bahasa), Bandung: Alfabeta, 2017.

[46] Aman, "Final examination test instruments for history subject in Yogyakarta, Indonesia: A quality analysis," Universal Journal of Educational Research, vol. 7, no. 12, pp. 2857-2866, 2019.

[47] D. U. Hargo, "Public lecture on understanding the archipelago's insights as insights into indonesian nationality in the context of building national resilience (in bahasa)," Kupang: Universitas Nusa Cendana, 2010.

[48] Slameto, Learning and Influencing Factors (in bahasa), Jakarta: PT Rineka Cipta, 2015. 